\title{
Deep Geological Characteristics and Ore Predition of Vein 175 in Linglong Gold Field in Jiaodong Area, Shandong Province
}

\author{
Zhu Suizhou, Chu Zhaobo, Li Lingbin, Miao Shuli, Xu Jian
}

Shandong Zhengyuan Geological Resources Exploration Co. 1td, Jinan, China

\section{Email address:}

Zhusz0208@163.com (Zhu Suizhou)

\section{To cite this article:}

Zhu Suizhou, Chu Zhaobo, Li Lingbin, Miao Shuli, Xu Jian. Deep Geological Characteristics and Ore Predition of Vein 175 in Linglong Gold Field in Jiaodong Area, Shandong Province. Earth Sciences. Vol. 10, No. 3, 2021, pp. 128-135. doi: 10.11648/j.earth.20211003.16

Received: May 31, 2021; Accepted: June 10, 2021; Published: June 21, 2021

\begin{abstract}
Located on the west coast of the Pacific Ocean, Jiaodong gold concentration area is one of the world's famous gold deposit areas. Its unique metallogenic environment and metallogenic background are favored by geologists of all countries, multi-level and multi-disciplinary scientific research work has been carried out in this area, and good results have been achieved. Linglong gold deposit, located $20 \mathrm{~km}$ northeast of Zhaoyuan, Shandong, is a quartz vein type gold deposit. Its veins are controlled by Linglong and Batouqing fault, and vein groups are developed in the area, there are 36, 48, 47, 53, 55, 108 and vein groups 175, among which vein group 175 is one of the main large vein group in Linglong Gold Mine. With the continuous exploitation and utilization of the shallow resources in Linglong Gold Mine, the amount of gold resources kept in Linglong Gold Mine has decreased sharply, and the enterprises are facing the situation of serious shortage of resources. In order to prolong the service life of mines, it is urgent to enlarge the geological reserves of gold deposits and to increase the prospecting and prospecting efforts in deep areas. In this paper are sunnarized the geological and metallogenic backgroud and geologcal characteristics of the ore vein groups 175 and ore-control factor, occurrence pattern of ore body and ore types are analyzed and metalogenic pattern described. Based on prospecting works in which ore is encountered gold ore reserve $192.44 \times 10^{4} \mathrm{t}(332+333)$ and gold metal reserve $8.5 \mathrm{t}$ are predicted by geologic block method bellow $-800 \mathrm{~m}$ level beteen line 11-101.
\end{abstract}

Keywords: Linglong Mining, Potouqing Fault, Regularity of Ore Formation, Ore Vein Group 175, Deep Ore Prediction, Shandong Province

\section{Introduction}

The Linglong gold mining area is located $20 \mathrm{~km}$ north of Zhaoyuan, Shandong province, Its geographical coordinates: E1202 $27^{\prime} 08^{\prime \prime}-\mathrm{E} 120^{\circ} 33^{\prime} 55^{\prime \prime}, \quad \mathrm{N} 37^{\circ} 26^{\prime} \quad 07^{\prime \prime}-\mathrm{N} 37^{\circ} 29^{\prime} 21^{\prime \prime} \quad$ (1). Linglong gold deposit belongs to Quartz Vein type gold deposit. Vein Group is developed in the gold deposit area. Ore vein group 175 is one of the main large vein group in Linglong gold deposit. The No. 175 pulse group is close to the broken head-qing fault, which is mainly composed of No. 176, No. 175 and No. 47 pulse. The elevation above- $200 \mathrm{~m}$ of the Vein Group is controlled by prospecting engineering, and the research degree is relatively high.

With the continuous exploitation and utilization of the shallow resources in Linglong Gold Mine, the amount of gold resources kept in Linglong Gold Mine has decreased sharply, and the enterprises are facing the situation of serious shortage of resources. In order to prolong the service life of mines, it is urgent to enlarge the geological reserves of gold deposits and to increase the prospecting and prospecting efforts in deep areas [1-4]. From December 2005 to December 2008, Shandong Zhengyuan Geological Resources Exploration Co., Ltd. carried out the exploration work of replacing resources in vein group No. 175 in this area. The total amount of drilling work was $22482.6 \mathrm{~m}$, the amount of tunnel work was $5894.06 \mathrm{~m}$, and the Exploration Fund was 31598.8 million yuan; In this paper, the systematic drilling engineering control is carried out for the 175th VEIN group drilling project under the elevation- $400 \mathrm{~m}$, the gold resources reserves are estimated by using the geological block method, and the amount of (333) gold ore is $428.06 \sim 10^{4} \mathrm{t}$, and the amount of metal is $24.8 \mathrm{t}$.

On the basis of the field work in 2009, the geological characteristics of the deep part of Vein Group 175 
(below-400m elevation) are deeply analyzed, and the vertical zoning regularity of gold mineralization in the deep part of Vein Group 175 is summarized, the deep metallogenic prognosis of the 11-101 exploration line of vein group 175 below $-800 \mathrm{~m}$ level is attempted.

\section{Geological Setting of Mineralization}

Linglong gold deposit is located at the eastern end of Zhaoye-Gold-Belt in Shandong Province. Its mineralization is controlled by Zhaoping Fault Zone. The main outcrops in the area are Guogezhuang formation of Jiaodong group and Piedmont formation of quaternary. The Mesozoic magmatism in the area is frequent and intense, which can be divided into three stages: (1) Neoproterozoic Linglong super-unit Zhuangzi Unit $\left(l D z \eta \gamma_{2}^{3}\right)$, Luoshan Unit $\left(l L \eta \gamma_{2}^{3}\right)$, Jiuqu Unit $\left(I J \eta \gamma_{2}^{3}\right)$; (2) Mesozoic Indo-chinese Wendeng super-unit Fushan Unit ( $\omega F \mu \gamma_{5}^{1}$ ); (3) Xishipeng Unit ( $\left.\mathrm{gX \eta} \gamma_{5}^{2}\right)$ of Guojialing superunit in early Mesozoic Yanshan Mountains. The structures in the area are mainly fault structures, and the larger ones are Linglong fault and Potouqing fault (Figure 1).

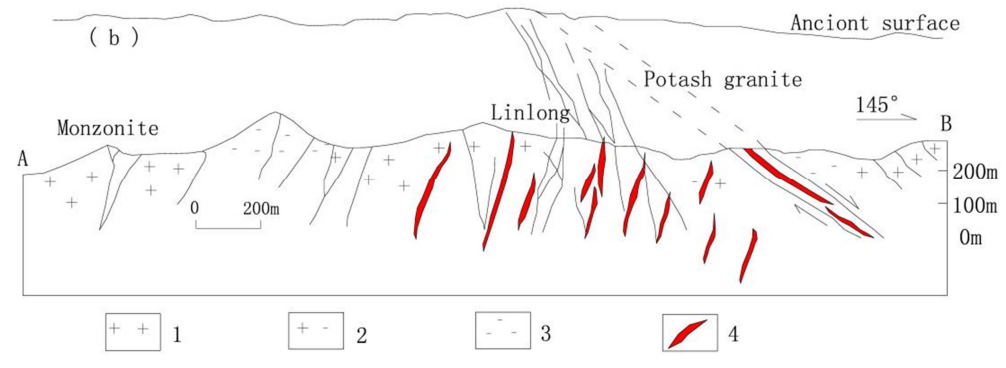

1. Monzonite; 2. Weakly Potassic Granite; 3. Potash granite; 4. Ore Body; 5. Fracture

Figure 1. Structural evolution sketch of Linglong fault and Potouqing fault.

The strike of the Linglong fault is NE2 $25^{\circ}-35^{\circ}$, the dip of the south segment is SE, the dip of the north segment is NW, and the dip angle is $65^{\circ}-85^{\circ}$. The length of the fault is about $4.6 \mathrm{~km}$ and the width is $50-150 \mathrm{~m}$. It has silicification, potassium, chlorite and sericite-quartzization. The shallow part of the fault zone is a long-term active fault which existed before mineralization and continued to be active after mineralization. In the deep part of Linglong fault zone, potassium and sericite alteration are found, and pyrite is found in local area. The distribution of pyrite is scattered and fine net vein, and the gold grade $(\mathrm{Au})$ is between $0.30 \times 10^{-6}$ and $1.05 \times 10^{-6}$, up to $2.5 \times 10^{-6}$.

The Potouqing fault is characterized by NE60-70 $0^{\circ}$ strike, trends SE, dip angle $40^{\circ}$, width $250-340 \mathrm{~m}$ and width up to $700 \mathrm{~m}$, the tectonite group is composed of cataclastic granite, granitic cataclasite, cataclastic rock, tectonic Breccia, mylonite and fault gouge. The tectonite has undergone hydrothermal alteration or mineralization to varying degrees and belongs to rock-controlling and ore-controlling structures [5]. The Fault Gouge developed in the footwall of the fracture zone and is the main fracture surface. There are sericitization, potash, silicification, carbonation and chlorite alteration in the country rocks, and the mineralization alteration includes pyrite, lead-zinc, chalcopyrite, gold and silver mineralization. In general, the fracture zone is wider, the rock is strong, the alteration is strong, the footwall is strong, the mineralization is strong, the gold ore body is located in footwall. The No. 175 Vein group in Linglong gold Mine is close to the Poutouqing fault.

\section{Geological Characteristics of the Deposit}

\subsection{Geological Characteristics of Vein Group 175}

In this paper, the vertical zoning of gold mineralization in the deep part of Vein Group 175 (below-400m elevation) is summarized through deep analysis of geological characteristics and comparative study of geological prospecting data in the past, the occurrence characteristics of deep gold orebody can be obtained (2).

(1) Secondary Veins present laterally on the side of the main vein. The Linglong gold field is thought to be composed of structural alteration and mineralization zones of different directions and stages [5]. The alteration zoning of the deposit is the product of tectonically controlled hydrothermal diagenesis and mineralization [6]. Figure 2 shows that 175 main veins of No. 175 have 175 No. 1 veins at Elevation-10m, with trends SE, dip angle $80^{\circ}$, gradually changing NW direction when extending to- $140 \mathrm{~m}$, and then extending to $45-72 \mathrm{dip}$ angle at elevation-250m, there are 175 No. 2 veins with NW dip and dip angle of $45^{\circ} \sim 72^{\circ}$, extending to deep gradually, and 175 No. 3 veins still have similar regularity. To sum up, the ore veins have the regularity of secondary veins side-by-side.

(2) Equidistant distribution of ore veins. Figure 2 shows that there are several branches of vein No. 175 below $+130 \mathrm{~m}$ elevation. From top to bottom, 175 branches of vein No. 1,175 branches of vein No. 2 and 175 branches of vein No. 3 are arranged in sequence. Each vein has a head dip SE and gradually changes to NW, dip angle $45^{\circ} \sim 72^{\circ}$; Each branch vein has the characteristic of nearly equidistant distribution, the vein spacing is about $120 \mathrm{~m}$. Because the ore body is strictly controlled by the ore vein, the ore body has the characteristics similar to the ore vein.

(3) The ore bodies are distributed obliquely in the lode. Obliquity law is a common geological phenomenon in vein-type gold deposits, that is, the vein appears obliquity 
and pinch-out in strike and dip, and the ore body accumulates in stages in the vein. The scale, shape and occurrence of ore veins and orebodies are strictly controlled by fault structures, which often provide favorable places for gold mineralization. According to the geological data of the mining area, the fault structures in this area extend slowly in strike, and the gold mineralization is enriched in dip. There are many orebodies in the exposed veins, all of which have NW dip, dip angle ranging from $45^{\circ}$ to $60^{\circ}$, and $2 \mathrm{~m}$ to $30 \mathrm{~m}$ interval extension (table 1).

Table 1. Geological characteristics of ore bodies in Linglong mining area.

\begin{tabular}{|c|c|c|c|c|c|c|c|}
\hline \multirow{2}{*}{ Lode number } & \multirow{2}{*}{$\begin{array}{l}\text { Orebody } \\
\text { numbering }\end{array}$} & \multicolumn{2}{|l|}{ Attitude } & \multirow{2}{*}{$\begin{array}{l}\text { OREBODY scale } \\
\text { (long } \times \text { wide) }(\mathrm{m})\end{array}$} & \multirow{2}{*}{$\begin{array}{l}\text { Ore rade } \\
\left(\times 10^{-6}\right)\end{array}$} & \multirow{2}{*}{ Vein type } & \multirow{2}{*}{ Control levation (m) } \\
\hline & & Inclinations $\left({ }^{\circ}\right)$ & Obliquity $\left({ }^{\circ}\right)$ & & & & \\
\hline \multirow{3}{*}{175 No. 1} & $\mathrm{I}-1$ & $333^{\circ}$ & $50^{\circ}$ & $100 \times 10.21$ & 4.00 & Altered Rock & -462 \\
\hline & $\mathrm{I}-2$ & $333^{\circ}$ & $48^{\circ}$ & $100 \times 3.15$ & 4.22 & Altered Rock & -480 \\
\hline & $\mathrm{I}-3$ & $333^{\circ}$ & $45^{\circ}$ & $100 \times 0.63$ & 1.81 & Altered Rock & -500 \\
\hline \multirow{3}{*}{175 No. 2} & II-1 & $343^{\circ}$ & $50^{\circ}$ & $120 \times 4.10$ & 2.45 & Altered Rock & -590 \\
\hline & II-2 & $343^{\circ}$ & $57^{\circ}$ & $120 \times 0.45$ & 1.61 & Altered Rock & -612 \\
\hline & II-3 & $343^{\circ}$ & $58^{\circ}$ & $120 \times 0.45$ & 1.04 & Altered Rock & -666 \\
\hline
\end{tabular}

(4) The ore body has vertical zonation. According to the analysis of geological data, the quartz vein and the transitional vein of Linglong gold deposit have similar vertical zoning of mineralization belt, but the occurrence level of the enrichment belt of these two types of veins is slightly different from that of the altered lithologic vein. The actual production data show that the mineralization is strong and the ore body is rich in the range of $-200 \mathrm{~m} \sim-320 \mathrm{~m}$, the mineralization is weak and the gold ore body is weak in the range of $-320 \mathrm{~m} \sim-420 \mathrm{~m}$, the mineralization is strong and the ore body is rich in the range of-420m -470m. In the range of-470 $\sim-520 \mathrm{~m}$ elevation, the mineralization is weak and the gold ore body is relatively weak, and in the range of-520 $\sim-570 \mathrm{~m}$ elevation, the mineralization is strong and the ore body is rich. That is to say, the weak mineralization belt and the rich belt of orebody are vertical zonation. The analytical results of the samples described in Table 2 also indicate that the ore bodies hosted by Vein group 175 have vertical zonation.

(5) The ore veins in the shallow part merge and thicken to the deep, and the ore grade decreases. The 175 No. 1 veins are located in the upper part of the 175 No. 2 veins, which belong to the 175 veins. On the whole, 175 No. 1 and 175 No. 2 veins have the characteristic of merging and separating alternately, and the intersection elevation extends from the East to the West to the deep. The 175 No. 1 veins appeared gradually close to each other on the $53 \mathrm{rd}$ line, and rejoined the 175 No. 2 veins on the 89 th line. The vein width is $17 \mathrm{~m}$ and $38 \mathrm{~m}$ respectively before the two veins meet. After the vein meets, the vein width becomes wider, the alteration becomes stronger, and the rock is broken. The results of the sample analysis described in table 3 show that the veins become thicker and lower in grade when they meet. But the ore bodies are developed near the junction, which is the favorable area for mineralization.

Table 2. Characteristics of vertical zoning ore bodies.

\begin{tabular}{llllll}
\hline \multirow{2}{*}{$\begin{array}{l}\text { Sequence } \\
\text { number }\end{array}$} & $\begin{array}{l}\text { Sampling } \\
\text { elevation }\end{array}$ & $\begin{array}{l}\text { Orebody } \\
\text { numbering }\end{array}$ & $\begin{array}{l}\text { Sample } \\
\text { length/m }\end{array}$ & $\mathbf{\omega}(\mathbf{A u}) / \times \mathbf{1 0}^{-\mathbf{6}}$ & Analysis results \\
\hline 1 & -230 & I & 1.00 & 3.12 & Activated Carbon Adsorption iodometry \\
2 & -270 & I & 0.88 & 9.48 & Altered rock type \\
3 & -320 & I & 1.25 & 2.56 & Activated Carbon Adsorption iodometry \\
4 & -420 & II & 1.26 & 1.98 & Activated Carbon Adsorption iodometry \\
5 & -450 & II & 1.02 & 9.73 & Altered rock type \\
6 & -470 & II & 1.34 & 3.28 & Activated Carbon Adsorption iodometry \\
7 & -520 & III & 0.90 & 1.89 & Activated Carbon Adsorption iodometry \\
8 & -550 & III & 1.12 & 3.27 & Activated Carbon Adsorption iodometry \\
9 & -570 & III & 0.80 & 2.15 & Activated Carbon Adsorption iodometry \\
\hline
\end{tabular}

Table 3. Analysis of samples collected from Linglong mining area.

\begin{tabular}{|c|c|c|c|c|c|c|c|}
\hline \multirow{2}{*}{ Sequence number } & \multirow{2}{*}{ Orebody umbering } & \multirow{2}{*}{ Control Engineering } & \multirow{2}{*}{ Thickness/m } & \multicolumn{3}{|c|}{ Analysis results } & \multirow{2}{*}{$\begin{array}{l}\text { Elevation/ } \\
\text { m }\end{array}$} \\
\hline & & & & Sample size & length/m & $\omega(\mathrm{Au}) / \times 10^{-6}$ & \\
\hline 1 & \multirow{4}{*}{175 No. 1} & \multirow{2}{*}{ ZK89-1 } & \multirow{2}{*}{$17 \mathrm{~m}$} & $\mathrm{H} 48$ & 1.10 & 4.12 & $-740 m$ \\
\hline 2 & & & & H52 & 0.28 & 13.56 & $-756 m$ \\
\hline 3 & & \multirow{2}{*}{ ZK89-2 } & \multirow{2}{*}{$84 \mathrm{~m}$} & H16 & 1.00 & 0.05 & $-940 m$ \\
\hline 4 & & & & $\mathrm{H} 17$ & 1.00 & 0.05 & $-940 m$ \\
\hline 5 & \multirow{3}{*}{175 No. 2} & ZK89-1 & $38 \mathrm{~m}$ & H16 & 0.93 & 1.36 & $-880 m$ \\
\hline 6 & & \multirow{2}{*}{ ZK89-2 } & \multirow{2}{*}{$84 \mathrm{~m}$} & $\mathrm{H} 26$ & 1.00 & 0.05 & $-940 m$ \\
\hline 7 & & & & $\mathrm{H} 27$ & 1.00 & 0.05 & $-940 m$ \\
\hline
\end{tabular}




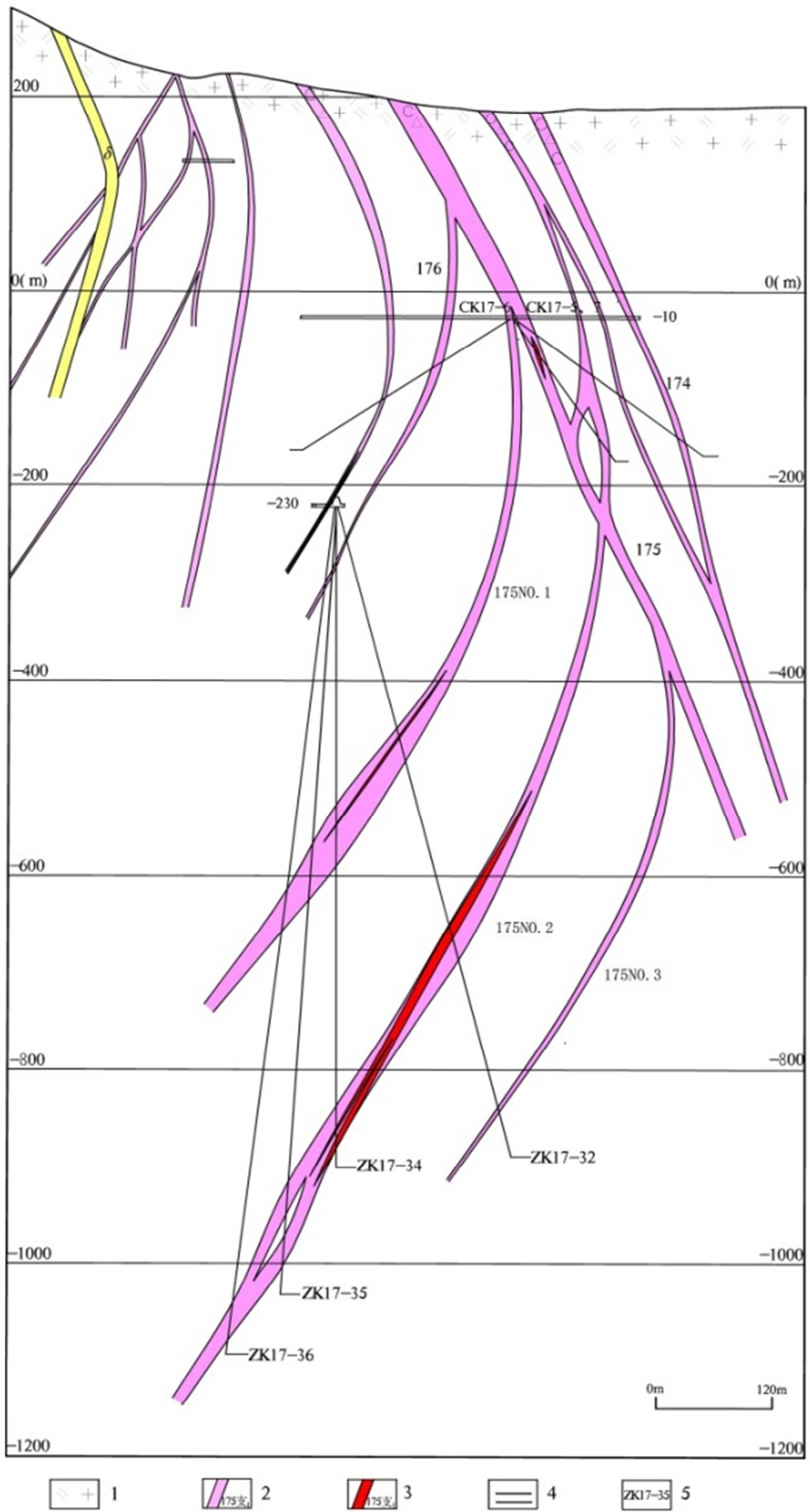

1. Adamellite;.2 Diorite dikes. 3 Lode. 4 Orebody. 5 Road Works; 6. Bore Hole

Figure 2. Scetion sketch along line 17 in Linglong mining area.

\subsection{Orebody Characteristics}

There are six gold ore bodies in vein group No. 175, and the ore types are mainly filled quartz vein type and cataclastic altered rock type, followed by the transitional type between them. There are two gold orebodies in 175 No. 1 veins, which are 175 No. 1-1 and 175 No. 1-2 respectively, and four gold orebodies in 175 No. 
2 veins, which are 175 No. 2-1,175 No. 2-2,175 No. 2-3 and 175 No. 2-4 respectively. The gold orebodies are represented by 175 No. 1-1,175 No. 2-1 and 175 No. 2-2.

(1) 175 No. 1-1 orebodies. 175 NO. 1-1 orebodies are vein-like, gently undulating along strike and dip, and locally expanding. The strike of the orebody extends $810 \mathrm{~m}$, dip depth $396 \mathrm{~m}$, trends $43^{\circ}-65^{\circ}$, dip NW, dip angle $48^{\circ}-72^{\circ}$. The host rocks are pyrite sericite, Pyrite sericite-quartzized granite and other altered rocks. The thickness of orebody is $0.27-5.00 \mathrm{~m}$, the average thickness is $3.12 \mathrm{~m}$, and the thickness variation coefficient is $109.81 \%$. The single gold grade $(\mathrm{Au})$ is $1.00 \times 10^{-6} \sim$ $9.85 \times 10^{-6}$, the average gold grade $(\mathrm{Au})$ is $3.35 \times 10^{-6}$, the grade change coefficient is $75.92 \%$, and the ore body is of uniform distribution of useful components.

(2) 175 No. $2-1$ ore bodies. 175 No. 2 -1 orebodies are vein-like, with gentle undulation along trends and dip. Trends $30^{\circ} \sim$ $55^{\circ}$, dip NW, dip angle $60^{\circ} \sim 75^{\circ}$. The host rocks are altered rocks such as pyrite sericite, Pyrite sericite-quartzized granite and pyrite-mineralized quartz veins. The trend of the orebody extends $1325 \mathrm{~m}$, the dip extends $560 \mathrm{~m}$, the thickness of the orebody is $0.49 \sim 2.93 \mathrm{~m}$, the average thickness is $1.05 \mathrm{~m}$, and the thickness variation coefficient is $65.63 \%$. The single gold grade $(\mathrm{Au})=$ $1.00 \times 10^{-6} \sim 33.37 \times 10^{-6}$, generally between $1.20 \times 10^{-6} \sim$ $7.00 \times 10^{-6}$, the average gold grade $(\mathrm{Au})=4.22 \times 10^{-6}$, the grade change coefficient is $181.43 \%$, which belongs to the non-uniform distribution of useful components.

(3) 175 No. 2-2 orebodies. The 175 No. 2-2 orebodies are vein-like and show gentle undulation along trends and dip. The trends extension of the orebody is $225 \mathrm{~m}$ and the dip extension is $297 \mathrm{~m}$. trends $30^{\circ} \sim 55^{\circ}$, dip NW, dip angle $60^{\circ} \sim 75^{\circ}$. The host rocks are altered rocks such as pyrite sericite, Pyrite sericite-quartzized granite and pyrite-mineralized quartz veins. The thickness of orebody is $6.77-20.17 \mathrm{~m}$, the average thickness is 12.19 $\mathrm{m}$, and the thickness variation coefficient is $81.92 \%$. The single gold grade $(\mathrm{Au})=1.04 \times 10^{-6} \sim 210.16 \times 10^{-6}$, generally $1.50 \times 10^{-6} \sim 10.00 \times 10^{-6}$, the average gold grade $(\mathrm{Au})=12.41 \times 10^{-6}$, the grade change coefficient is $267.79 \%$, which belongs to the non-uniform distribution of useful components.

\subsection{Mineral Composition Characteristics}

(1) Mineral composition of ore. The gold ores are mainly pyrite quartz veins and pyrite sericite quartzite. The metallic minerals in the gold ores are mainly pyrite, Chalcopyrite, Galena and sphalerite, and occasionally magnetite and tetrahedrite. The nonmetallic minerals are mainly quartz, plagioclase, potash feldspar and sericite, second for Calcite, biotite, chlorite, and a small amount of hornblende, muscovite, carbonate minerals, apatite, sphene and so on. Figure 3 is a photomicrograph of the ore. There are metallic minerals native gold (Figure 3A), silver gold, pyrite (Figure 3B), chalcopyrite (Figure 3C), Galena, sphalerite, and occasionally magnetite and tetrahedrite Non-metallic minerals are mainly quartz, plagioclase, potash feldspar (Figure 3d), sericite, calcite, biotite, chlorite, and a small amount of Hornblende, Muscovite, carbonate minerals, apatite, sphene [7].

(2) Chemical composition of ore. Table 4 shows the results of chemical multi-element analysis of gold ores. The results show that the main useful components of Gold Ores are $\mathrm{Au}, \mathrm{AG}$ and $\mathrm{S}$, with mean values of $4.185 \times 10^{-6}$, $7.95 \times 10^{-6}$ and $3.60 \times 10^{-2}$ respectively.

Table 4. Multi-elements analysis of ore.

\begin{tabular}{|c|c|c|c|c|c|c|c|c|c|}
\hline & $\omega(\mathrm{Au}) / 10^{-6}$ & $\omega(\mathrm{Ag}) / 10^{-6}$ & $\omega(\mathrm{Cu}) / 10^{-2}$ & $\omega(\mathrm{Pb}) / 10^{-2}$ & $\omega(\mathrm{Zn}) / 10^{-2}$ & $\omega(\mathrm{Sn}) / 10^{-6}$ & $\omega(\mathrm{As}) / 10^{-6}$ & $\omega(\mathrm{Sb}) / 10^{-6}$ & $\omega(\mathrm{Bi}) / 10^{-6}$ \\
\hline Pyrite Quartz Vein & 3.84 & 13.1 & 0.45 & 0.03 & 0.01 & 4.17 & 0.0014 & 0.20 & 3.03 \\
\hline Pyrite sericite & 4.53 & 2.80 & 0.005 & 0.01 & 0.01 & 3.62 & 0.0005 & 0.10 & 1.58 \\
\hline Average & 4.185 & 7.95 & 0.2275 & 0.02 & 0.01 & 3.895 & 0.0009 & 0.15 & 2.305 \\
\hline & $\omega(\mathrm{Ni}) / 10^{-6}$ & $\omega(\mathrm{Cr}) / 10^{-6}$ & $\omega(\mathrm{Ti}) / 10^{-2}$ & $\omega(S) / 10^{-2}$ & $\omega(\mathrm{P}) / 10^{-2}$ & $\omega(\mathrm{Mn}) / 10^{-6}$ & $\omega(\mathrm{Co}) / 10^{-6}$ & $\omega(\mathrm{Mo}) / 10^{-6}$ & $\omega(\mathrm{Sr}) / 10^{-6}$ \\
\hline Pyrite Quartz Vein & 73.33 & 116.67 & 0.13 & 4.4 & 0.004 & 150.0 & 50.0 & 13.33 & 25.0 \\
\hline Pyrite sericite & 60.00 & 80.00 & 0.16 & 2.8 & 0.006 & 175.0 & 67.5 & 11.22 & 25.0 \\
\hline Average & 66.665 & 98.335 & 0.145 & 3.6 & 0.005 & 162.5 & 58.75 & 12.275 & 25.0 \\
\hline
\end{tabular}
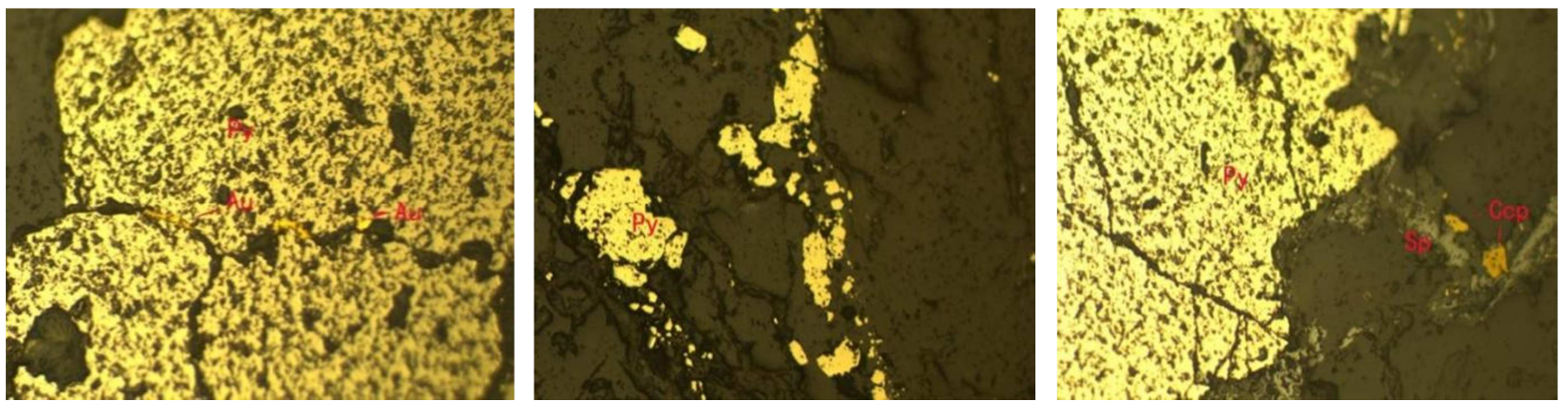

Figure 3. Micrograph of ore.

(a) under gold orthogonal microscope of crystal gaps between pyrite grains, (b) under self-shaped-semi-self-shaped distribution of pyrite grains, and (C) under orthogonal microscope of chalcopyrite in pyrite fractures, (D) polarographic image of Potassic Granite (20000) 
(3) Beneficial and associated ingredients. AU is the main beneficial component in the ore, its content (mass fraction) varies widely, $(\mathrm{Au})$ ranges from $1 \times 10^{-6}$ to $46.18 \times 10^{-6}$, and the single sample is the highest $(\mathrm{Au})=$ $46.18 \times 10^{-6}$. There is no regularity in the variation of gold grade along strike and dip, the gold grade is generally related to the ore type and alteration degree of the ore body. AG is one of the main beneficial associated components in the ore. Its $(\mathrm{Ag})$ values range from $1.20 \times 10^{-6}$ to $22.30 \times 10^{-6}$ with an average $(\mathrm{Au})=4.95 \times 10^{-6}$. The content $\mathrm{S}$ of is between $0.67 \%$ and $5.78 \%$, with an average of $2.31 \%$. the $\mathrm{S}$ value is related to ore type and mineralization degree.

(4) Mineralization stage. According to the field observation, laboratory identification and the division of regional metallogenic stages, the mineralization stage is divided into four stages: pyrite-quartz stage, gold-quartz fine-grained pyrite stage, gold-silver polymetallic sulfide stage, gold carbonate stage. According to the data of geological and mineral exploration, there are two mineralization types of quartz vein type and altered rock type in vein group No. 175, which are obviously symmetrical zonal distribution. In most cases, quartz vein type gold ore or pyrite quartz vein type gold ore is commonly found in the vein body center. According to the mining data of Linglong Gold Mine, the opalescent quartz and pyrite particles in the vein have obvious crushing structure, many cracks and very low gold content; polymetallic sulphides occur as medium-fine grained, disseminated, veined or interspersed in cracks of coarse grained pyrite, and their gold-bearing properties are good.

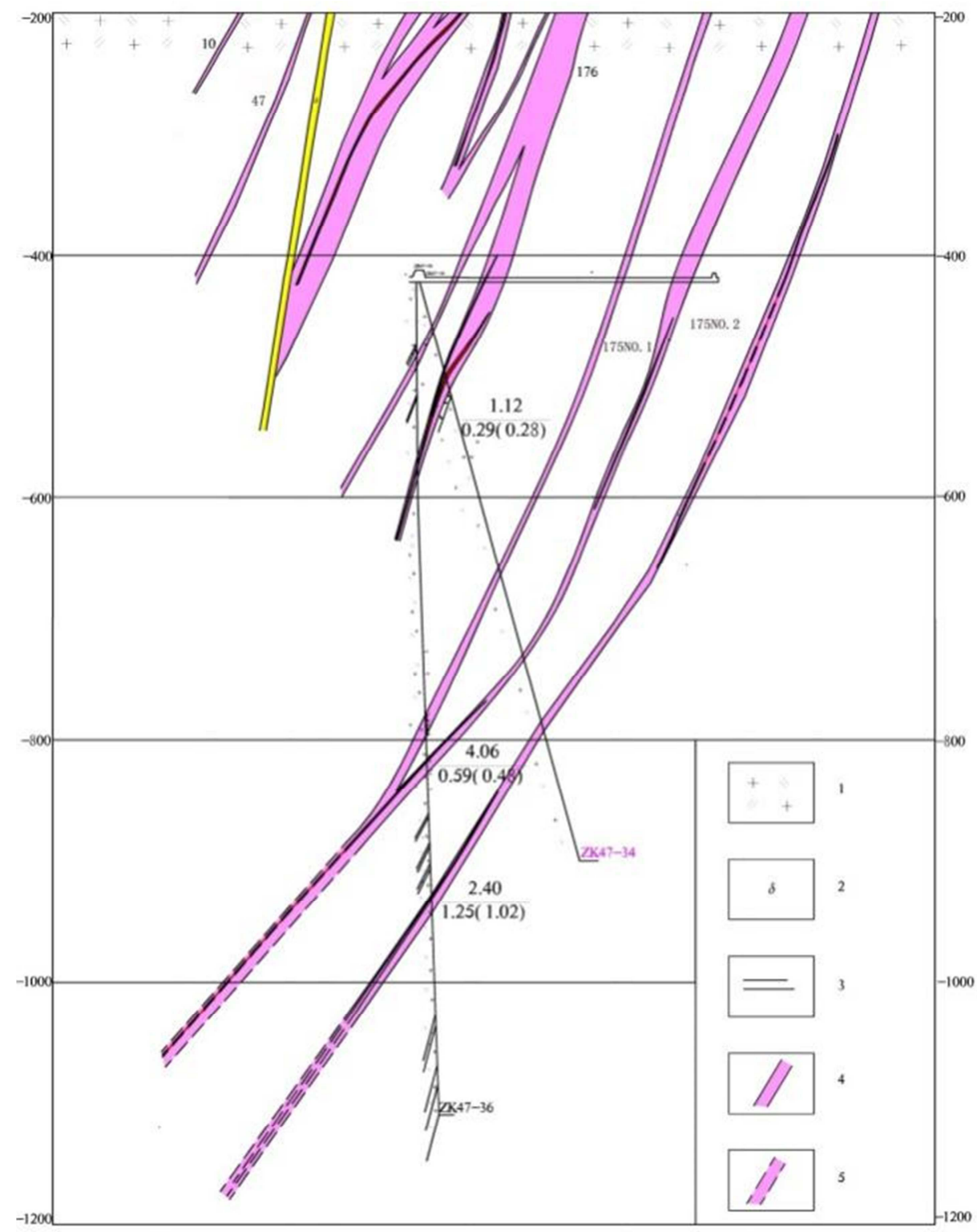

1. Adamellite; 2. Diorite porphyrite; 3. Orebody; 4. Control the lode; 5. Forecast Lode; 6. Road Works; 7. Underground drilling

Figure 4. Map showing ore prediction results along line 47 in ore vein group 175 


\section{Deep Orebody Prediction}

The No. 175 Vein Group of Linglong Gold Mine is located in the West side and lower wall of the Botouqing fault, and controlled by the secondary faults of the Poutouqing fault. The fracture direction is $55^{\circ} \pm$, the dip angle is between $40^{\circ}$ and $50^{\circ}$, and the trend of dip to depth is $30^{\circ} \pm$. The footwall of the fault zone is characterized by secondary and low-sequence faults and fractures, which is the hosting space of quartz vein type gold veins. The vein group is generally distributed and varied with the main compression-torsion structural rock zone, and the dip is NW, NNW and NE.

(1) Different types of fault systems provide different physical chemistry environments for hydrothermal activity and gold enrichment, resulting in different types of ore veins. Linglong gold deposit is a typical vein-type deposit. Most of the veins are gold-bearing quartz veins, sulfide-bearing quartz veins, sulfide-bearing quartz veinlets, etc. In the tectonic activity, the intersection area provides space for the gold mineral enrichment, the gold-bearing hydrothermal solution repeatedly precipitates the enrichment to form the gold ore body. According to the mining means of production, there are many industrial ore bodies near the intersection of the two veins in Linglong mining area, which are large in scale and high in grade $(\mathrm{Au})$ up to $422.87 \times 10^{-6}$. The ore veins extend to the deep with the dip angle from $40^{\circ}$ to $80^{\circ}$, and the possibility of the intersection of the two veins is very high. Therefore, the near junction of the two deep veins is of great significance for ore prospecting.

(2) the existing geological prospecting data show that the ore bodies in the same vein generally occur at intervals of $200-300 \mathrm{~m}$ and their scale is generally $200-500 \times 0.80-6.20$ $\mathrm{m}$, and the elevation of the ore bodies is $-1000 \mathrm{~m} \pm$, most of the ore veins are shallow in depth and extend to deep unclosed. Based on this, it can be predicted that the control elevation of the orebody is $-1600 \mathrm{~m}$ or deeper, and the potential of deep prospecting is great [8-11].

Based on the field work in 2009, the geological characteristics of the deep part (below-400m) of vein group No. 175 in Linglong gold mining area are analyzed, the deep prospecting of vein group No. 175 in Linglong gold mining area is predicted by using the geological block method and the gold ore resource $(332+333)$ is $192.44 \times 10^{4} \mathrm{t}$ below the elevation of 11-101 exploration line- $800 \mathrm{~m}$ of vein group No. 175 in Linglong gold mining area, 8.5t of metal.

\section{Conclusion}

(1) Affected by the structure of Potouqing fault, the veins and deep gold deposits in linglong mining area have the law of ne extension and lateral declination. The deep ore type is mainly altered rock type, and the second is quartz vein, and the thickness grade of the veins decreases linearly.

(2) Most of the deep ore veins are in the shape of "Y" intersection, which provides space for the enrichment of gold minerals. The gold-bearing hydrothermal solution is repeatedly precipitated and enriched, resulting in high grade.

(3) The deep orebody of No. 175 vein group has vertical zonation, the orebody can extend to- $1600 \mathrm{~m}$ or deeper, and the deep orebody has huge resource potential.

\section{Note}

(1) Shandong Zhengyuan Geological Resources Exploration Co., Ltd. Detailed investigation report of Vein Deep Gold Mine No. 175, linglong gold field, Zhaoyuan City, Shandong Province [r]. Jinan: Shandong Zhengyuan Geological Resources Exploration Co., Ltd., 2012.

(2) Shandong Gold Mining (Linglong) Co., Ltd. Prospecting method and prediction of structural deformation lithofacies mapping in Linglong Gold Deposit [R]. Zhaoyuan, Shandong: Shandong Gold Mining (Linglong) Co., Ltd., 2010.

\section{References}

[1] Li Junfeng, Wu Jichun, Song Quanwu, et Al. Development and utilization of low grade ores in Linglong gold field [J]. Golden Science and technology, 2010, 18 (2): 63-66.

[2] Li Bile, Wang Li, Huo Liang, etc. Ore-forming fluid characteristics and genesis of 52 \# Vein Group in Linglong gold deposit, Jiaodong [i]. Advances in natural science, 2009, 19 (1): 51-60.

[3] Jiang Weimin, Habenhai, Wang Qiliang, et Al. Location analysis of deep orebody of Jiuqu and Dakaitou orebodies in Linglong gold field [J]. Golden Science and technology, 2004, 12 (4): $17-21$.

[4] Kong Lingzhi, Zhu Suizhou, Han Yunsong, etc. Comprehensive analysis of geophysical characteristics and prospecting prediction of linglong fault zone in Shandong Province [j]. Science and technology of gold. 2012, 20 (4): 117-122.

[5] Lu Guxian, Hou Chengqiao, Guo Tao, etc. Prediction of the second enrichment zone of deep resources in Linglong gold field [J]. Gold. 2006, 27 (260): 47-53.

[6] Occurrence and location of vein 53 orebody in Linglong Gold Orefield, Song Quanwu, Dai Lixin, Lu Renjiang, etc. Gold. 2006, 27 (260): 75-78.

[7] Deep exploration progress of vein group No. 175 in Linglong Gold Orefield, Jiaodong. Innovation of mine geology theory and practice. 2014, 96-98.

[8] LV Guxian, Kong Qingcun, Deng Jun, et Al. Study and calculation of deep mineralization of linglong gold ore field, Shandong Province [j]. Science Bulletin. 1995, 40 (15): 1399-1402.

[9] LV Guxian, Kong Qingcun, Deng Jun, et Al. Study and calculation of deep mineralization of linglong gold ore field, Shandong Province [j]. Geology Review. 1996, 42 (6): $550-559$. 
[10] Wujichun, LV Guxian, Ren Hong, et AL, Deep prediction-tectonic altered lithofacies geological survey and deep prospecting of Goaf in Jiuqu gold mining area, linglong district, Zhaoyuan City, Shandong Province [j]. Geological Bulletin. 2011, 30 (4): 579-587.
[11] LV Guxian, Wu Jichun, Hu Baoqun, et Al. Geology and metallogenic regularity of Linglong gold field in Jiaodong [J]. Journal of Mineralogy. 2011, 42 (6): 74-76. 